\title{
0 potrzebie ochrony czci w świetle wypowiedzi arcybiskupa Józefa Życińskiego
}

Prof. DR hab. ANDRZEJ Zoll

Uniwersytet Jagielloński

Dwudziestolecie niepodległej Polski było jednocześnie dwiema dekadami pełnienia posługi biskupiej i arcybiskupiej ks. Józefa Życińskiego, dekadami przynoszącymi spełnienie nadziei kilku pokoleń Polaków, a równocześnie objawiającymi głębokie podziały społeczne, światopoglądowe, związane często $z$ innym widzeniem przyszłości Polski, jej miejsca w Europie, relacji pomiędzy państwem a Kościołem, także relacji pomiędzy państwem a pojedynczym człowiekiem poddanym jego jurysdykcji. Te podziały nie były jedynie prostym spadkiem po okresie PRL. Społeczeństwo polskie nie było w początkowych latach transformacji w pierwszym rzędzie podzielone na zwolenników przemian ustrojowych i na tych, którzy uważali, że PRL należało zachować, wprowadzając może do systemu demokracji ludowej większe lub mniejsze korekty. Tych ostatnich nie było tak wielu. Znacznie głębsze podziały powstały wtedy między zwolennikami przemian. 
Dotyczyły one zarówno strategii przeprowadzania transformacji, jak i jej zakresu i głębokości. Przede wszystkim podziały w społeczeństwie dotyczyły także rozliczenia z przeszłością, rozliczenia nie tylko z ustrojem okresu zniewolenia, ale także z osobami odpowiedzialnymi za zniewolenie i sprawcami zbrodni okresu komunistycznego. Ten powód podziału był i jest w Polsce nadal obecny. W późniejszych latach polskiej transformacji, szczególnie po wstąpieniu do Unii Europejskiej, zarysował się nowy podział, w dużym stopniu wynikający z różnego podejścia do zmian obyczajowych zachodzących w Europie. Oba te źródła konfliktu, nie pokrywając się bynajmniej, lecz raczej krzyżując, w znacznym stopniu wpłynęły na dzisiejszy stan głębokiego zróżnicowania, by nie mówić o wrogości, przynajmniej dwóch obozów na scenie politycznej Polski. Te dwa obozy, co czasami próbuje się narzucić, nie pokrywają się z podziałem społeczeństwa na osoby wierzące i niewierzące. Nie chodzi też oczywiście o podział społeczeństwa na lepsze i gorsze sorty albo na obciążonych genem zdrady i tych, którzy od tej skazy są wolni. Ten rzeczywisty podział był przedmiotem szczególnej troski, której wyraźny ślad spotykamy w pismach abp. Józefa Życińskiego. W tej trosce wyraźne są dwa aspekty: pierwszy odnosi się do konieczności przeprowadzenia dokładnej oceny przeszłości i wyciągnięcia z niej wniosków dla teraźniejszości i przyszłości oraz wyraźnej oceny zmian obyczajowości, odróżnienia dobra i zła, drugi dotyczy formy prowadzenia takiego rozliczenia i oceny. Szczególnie 
ten ostatni aspekt będzie ważny z punktu widzenia tematu mojego wystąpienia. Ochrona czci drugiego człowieka wiążąca się z przyrodzoną i niezbywalną godnością każdego była zawsze punktem wyjścia rozważań Księdza Arcybiskupa, była powodem odrzucenia przez niego wszelkiej mowy nienawiści lub nawet tylko pomówień naruszających dobre imię osoby pokrzywdzonej.

Niezwykle charakterystyczna dla toku rozumowania abp. Życińskiego wobec osób z dalekiego mu ideologicznie obozu jest następująca wypowiedź sprzed siedmiu laty, jakże bardzo aktualna również dzisiaj. „Po co się martwić partyjną strategią lewicy? Sami są sobie winni i sami zapłacą cenę swych obecnych decyzji, kiedy do głosu dojdzie nowe pokolenie lewicy, dla którego oprócz władzy liczyć będą się także wartości etyczne" ${ }^{\text {. }}$. Tej wypowiedzi nie można odmówić waloru proroctwa. Klęska wyborcza polskiej lewicy jest konsekwencją pozostawania jej przywódców w sposobie myślenia bliskim lat późnego okresu PRL i zachowywania bardzo dużego dystansu wobec wartości etycznych tej formacji ideowej. Autor tych słów wręcz miał nadzieję, że młoda polska lewica sięgnie po te wartości, co umożliwi dialog z tymi, którzy swój obraz świata, tak jak i abp Życiński, wywodzili z innych podstaw etycznych. Nie ma w tej wypowiedzi cienia odrzucenia, braku szacunku dla reprezentujących odmienny, ale oparty na

1 J. Życiński, Bruderszaft z Kainem. Medytacje nad moralnym spadkiem po PRL, Poznań 1999, s. 36. 
wartościach etycznych, punkt widzenia. Ksiądz Arcybiskup wyraża też troskę o osoby zaliczane wówczas do obozu lewicy. Czytamy w dalszym ciągu przywołanej wypowiedzi: „Problem w tym, by obecnego pokolenia nie traktować jako generacji straconej, która banalizując zło, będzie unikać podstawowych problemów natury etycznej. Istnieje bowiem poważna część społeczeństwa, która była uwikłana w różnorodne formy niejednoznacznego etycznie współdziałania z ideologicznymi twórcami polskiego totalitaryzmu"2. Ksiądz Arcybiskup przestrzega przed traktowaniem tych wszystkich osób na równi z Humerem, a więc jako zbrodniarzy okresu komunizmu. Nie ma być odpowiedzialności zbiorowej. Nikt nie powinien być obarczany odpowiedzialnością za czyny, których sam nie popełnił. Ale abp Życiński, mówiąc o tej części społeczeństwa polskiego, stwierdza: „Nie powinni jednak również wyciszać swych sumień przy pomocy reinterpretacyjnych zabiegów, które niosą łatwą pociechę, tłumacząc, że każdy $z$ nas jest w pewnym sensie «kolegą Humera»"3. Nie wolno tym, którzy odrzucali w okresie PRL wspieranie ideologii komunistycznej, godzić się na taką reinterpretację, gdyż wtedy bardzo łatwo zatrzeć granice pomiędzy dobrem a złem. Nie wolno „pić bruderszaftu z Kainem”. To odrzucenie zła, sprzeciwianie się relatywizacji oceny polskiego totalitaryzmu, sprzeciwianie się zasłanianiu tego

2 Tamże, s. 38.

3 Tamże, s. 152. 
zła rzekomo ludzką twarzą czy wręcz nazywanie go totalitaryzmem humanistycznym, idzie w rozmyślaniach Księdza Arcybiskupa w parze z głęboko chrześcijańskim, ewangelicznym podejściem do osób, które ten system tworzyły i były jego funkcjonariuszami. $O$ tej postawie świadczy m.in. powołanie się na wspomnienia zakonnicy siostry Stanisławy Niemeczek witającej w Komańczy eskortowanego przez funkcjonariuszy UB Księdza Prymasa Wyszyńskiego. Cytuję fragment tych wspomnień za Księdzem Arcybiskupem. „Eskortujący patrzyli na moment powitania, na nasze przyjęcie i szacunek dla Więźnia, a podziwiając jego spokój, łagodność i życzliwość, szepnęli na uboczu «Ujmującego macie Prymasa»... My? - pomyślałyśmy. Dlaczego tylko my, a nie oni z nami... Zrobiło mi się żal tych młodych ludzi. Chodzili niby w dzień, a tak, jak gdyby nie widzieli światła"4. A przecież to wspomnienie mogło mieć treść zupełnie inną. Mogło zawierać surowe oceny postawy tych młodych ludzi służących totalitaryzmowi, przyczyniających się do pozbawienia wolności Prymasa. Inna mogła być też ocena tych wspomnień Księdza Arcybiskupa. Po co żałować tych ubeków? W rozważaniach abp. Życińskiego znajduje się pełna aprobata stosunku zakonnic do funkcjonariuszy UB, aprobata dojrzenia w nich człowieczeństwa, a nie tylko zła w pełnionej przez nich funkcji. Trzeba jednak z całą mocą podkreślić, że nie oznacza to tolerancji wobec zła i wobec niegodziwych czynów. Dla

4 Tamże, s. 150. 
abp. Życińskiego szczególnie niebezpieczny dla obecnego stanu polskiej debaty o przeszłości jest relatywizm, operowanie półprawdami, rozmywanie znaczeń podstawowych terminów, z pomocą których opisuje się oceniane poglądy i wydarzenia. Ksiądz Arcybiskup pisze: „Nie przywróci się etycznej wrażliwości, jeśli pozostaniemy na poziomie ogólników, unikając konkretnych pytań o prawdę i o odpowiedzialność moralną. Praktyka uników może prowadzić do reakcji łańcuchowej. W której zatarta zostanie różnica między moralnym dobrem i złem, zaś specjaliści od zacierania będą publicznie występować w roli moralistów czy ekspertów od ekumenizmu socjalistycznego"s. Te słowa nie są wcale dalekie od rzeczywistości. Znam podręcznik akademicki, w którym po 1989 roku w kolejnych wydaniach wyrażenie „humanizm socjalistyczny” zastąpiono „wartościami chrześcijańskimi”.

Nie można jednak doprowadzać procesu rozliczania się z przeszłością do absurdu. Nie jest tak, że osoby, które kwestionowały i kwestionują nadal procesy lustracyjne, są agentami, jak napisał jeden z czytelników do Księdza Arcybiskupa. To typowy dla totalitarnego myślenia podział na przyjaciół i wrogów. Kto nie jest naszego zdania, jest wrogiem. Niestety nie dotyczy to tylko lustracji, lecz jest postawą obecną współcześnie, o czym przekonujemy się bardzo często. Ten podział na przyjaciół i wrogów pociąga za sobą konkretne ofiary. Po opublikowaniu

5 Tamże, s. 154. 
tzw. listy Wildsteina przyszła do mnie, jako rzecznika praw obywatelskich, córka Aleksandra Kamińskiego. Nazwisko jej ojca znalazło się na liście, a ona wcześniej z IPN dostała dokument, że ojciec był ofiarą prześladowań w czasach stalinowskich. W wyniku umieszczenia nazwiska „Aleksander Kamiński” na liście, kilka szkół w Polsce anulowało patronat autora Kamieni na szaniec. Nie zgadzam się z wyrażanym wtedy komentarzem, że gdzie drwa rąbią, tam lecą wióry. Postawa przyjmująca prosty podział na przyjaciół i wrogów zmierza do wysiłku eliminowania konfliktu społecznego lub politycznego przez próbę zamknięcia ust należącym do drugiego obozu. Podział na humanitarny lub mniej humanitarny totalitaryzm będzie się opierał na sposobie zakładania knebla.

W sposób w pełni uzasadniony Ksiądz Arcybiskup wskazuje na zagrożenia wynikające z pomieszania ideologii totalitarnej z narodowym katolicyzmem. Wielokrotnie w swoich pismach tłumaczy, że katolicyzm nie może być narodowy. Jest bowiem ze swej istoty powszechny i nie odróżnia Polaka, Żyda, Araba czy Afrykanina. Przedwojenne hasła ONR-u i OZON-u przetrwały - zdaniem Arcybiskupa - w PRL w otoczeniu PAX-u i ZBOWiD-u, a dzisiaj także są obecne w środowiskach narodowo-radykalnych. Ta nauka abp. Życińskiego jest dzisiaj szczególnie potrzebna, by zapobiec szerzącej się ksenofobii i odrzuceniu innych. W tych właśnie środowiskach najbardziej groźna jest mowa nienawiści, w której atak na drugiego człowieka nie wynika z jego zachowania czy wyrażanych poglądów, ale 
jest dyktowany właściwościami tej osoby, na które nie ma ona żadnego wpływu albo ma go w bardzo ograniczonym stopniu. Powodem ataku może być kolor skóry, przynależność etniczna lub narodowa, wyznawana religia czy inne wyróżniające daną osobę cechy. Ksiądz Arcybiskup ostrzega, że nadal istnieje zapotrzebowanie na następców Kaina, „którzy pogańską krzepę połączą z apoteozą narodu, przybraną w pseudokatolickie ozdobniki”". Arcybiskup w tym kontekście zadaje niezwykle aktualne pytania: „Czy absurdalne obciążenie treści wiary programami politycznymi oraz poszukiwanie partii posiadających szczególne predyspozycje do realizowania tych właśnie programów nie jest jedynie dziedzictwem podejścia, które otrzymało wyjątkowo bolesną postać w upolitycznionych zniekształceniach chrześcijaństwa?”. „Czym usprawiedliwić podejmowane próby podnoszenia jakkolwiek pojętej postępowości lub narodowości do rangi czynników określających naturę katolicyzmu?" . W tak rozumianym przez wielu narodowym katolicyzmie tkwią dzisiaj korzenie mowy nienawiści, korzenie odrzucania osób inaczej myślących, traktowania ich za wrogów i zdrajców interesów narodowych. Nieważne są zasługi tych osób w czasach walki z komunizmem o niepodległą Polskę, a nawet z niemieckim okupantem. Nieważne są ich związki z Kościołem. Jeśli takie osoby nie podzielają poglądów tzw. obozu patriotycznego, zasługują

6 Tamże, s. 144.

7 Tamże, s. 147. 
w oczach przedstawicieli tego obozu na pogardę i odrzucenie jako wrogowie Polski i Kościoła. Będąc rzecznikiem praw obywatelskich, wielokrotnie stykałem się z objawami takich postaw i z ich ofiarami. Z wielką przykrością, jako katolik, interweniowałem w kurii warszawskiej w sprawie rozpowszechniania przez jedną z księgarń znajdujących się w podziemiu kościoła w centrum stolicy publikacji o treściach przepełnionych mową nienawiści, zawierających apoteozę poglądów antysemickich, a nawet gloryfikujących postępowanie nazistów wobec Żydów. Mimo upływu kilku lat od napisania przywołanego przeze mnie tekstu Księdza Arcybiskupa mamy dzisiaj do czynienia w Polsce z sytuacją, która wcale nie jest lepsza. Sytuacja międzynarodowa stanowi niestety także dobre paliwo dla tego typu ekscesów. Muszę w tym miejscu przywołać cytowany przez abp. Życińskiego fragment wiersza Antoniego Słonimskiego Dwie ojczyzny:

\section{$[\ldots]$}

W Twojej ojczyźnie do obcych w wierze

Bóg się nie zniża.

Moja ojczyzna świat cały bierze

W ramiona krzyża. [...]

Odrębny problem stanowi przywołana przez Księdza Arcybiskupa „platoniczna nieżyczliwość”, przejawiająca

8 Tamże, s. 168. 
się w agresji wobec drugiej osoby, nieufności wobec niej, oskarżeniach o niecne zachowania, bez obiektywnego uzasadnienia. Jako przykład takiej platonicznej nieżyczliwości przywołał Ksiądz Arcybiskup nagonkę na Jerzego Owsiaka. Ten przykład jest nadal aktualny, a platoniczna nieżyczliwość zmieniła się u niektórych, niestety też z kręgów kościelnych, w platoniczną nienawiść. Fenomen Wielkiej Orkiestry Świątecznej Pomocy mobilizujący dziesiątki, jeśli nie setki, tysięcy młodych ludzi wokół działań charytatywnych powinien być czynnikiem wiążącym Polaków, powinien łączyć ponad podziałami politycznymi lub światopoglądowymi. Inicjatywa ta nie neguje przecież w żadnym stopniu osiągnięć programów realizowanych przez Kościół lub inne podmioty aktywne w pomocy dla innych. Już przed kilku laty, gdy Ksiądz Arcybiskup pisał swoje rozważania, stwierdził: „zastanawiałem się, skąd bierze się u nas tyle platonicznej nienawiści, która każe nobliwym skądinąd osobom atakować każdego, kto ma odwagę coś zrobić" . Nie można pominąć powtórzenia fundamentalnego prawidła etyki chrześcijańskiej. W felietonie zatytułowanym Platoniczna nieżyczliwość Ksiądz Arcybiskup pisze: „Chrześcijańska kultura ducha wymaga zarówno odpowiedzialności za słowo, jak i szacunku dla osoby, która może błądzić, a mimo to pozostaje bliźnim wymagającym miłości”"

\footnotetext{
9 Tamże.

1o Tamże, s. 170.
} 
Ta miłość do drugiej osoby nie oznacza natychmiastowego wybaczenia popełnionych błędów. Oznacza raczej stworzenie szansy ich naprawienia i zadośćuczynienia za wyrządzoną drugiemu krzywdę. W felietonie - wspomnieniu Zygmunta Herberta - abp Życiński przywołuje należący już do klasyki dwuwiersz z Przesłania Pana Cogito:

[...] i nie przebaczaj zaiste nie w twojej mocy przebaczać w imieniu tych których zdradzono o świcie $[\ldots]$.

Arcybiskup Życiński odrzuca gotowość i misję tropienia wszelkiego zła przez tych, którzy przyjęli postawę sztucznej pryncypialności. Tacy sporządzają „katalogi wad naszych bliźnich, epatując zarówno osobistym głębokim zgorszeniem, jak i dyskretnie podkreślonym poczuciem własnej doskonałości"11. W czasie, gdy Ksiądz Arcybiskup pisał te słowa, nie było tak gęsto od pomówień w sieci internetowej. Istniały już jednak różne radiostacje i media stwarzające dla oskarżycieli nową jakość w środkach przekazu. W rozmyślaniach Arcybiskupa znajdujemy ostrzeżenie: „Ta nowa jakość w naszych środkach przekazu stanowi w istocie psychiczną formę linczu stosowaną przez jedno-, a czasem dwuosobowy trybunał. Oskarżonemu nie daje się wtedy żadnej możliwości obrony. Oskarżyciel natomiast ma nieograniczoną możliwość demonstrowania swoich

${ }_{11}$ Tamże, s. 185 . 
kompleksów i uraz. [...] Możliwości absurdalnych oskarżeń są praktycznie nieograniczone, odpowiedzialność żadna" ${ }^{12}$. W tekstach Księdza Arcybiskupa można znaleźć konstatację, że często rzucenie oskarżenia wobec drugiej osoby nie jest dyktowane troską o prawdę. Motywem takiego działania jest nierzadko pustka przybierająca postać frustracji przechodzącej w agresję $e^{13}$. Pustka ta może być formą tę̨snoty za postawą pryncypialnego Katona.

Znamienne są słowa abp. Życińskiego: „Myślę z szacunkiem o tych naszych bliskich, których potraktowano kamieniem proroków i którzy za swój wysiłek, zaangażowanie i poświęcenie otrzymali w najbliższym środowisku odpłatę w postaci pomówień, intryg czy jawnie absurdalnych oskarżeń" ${ }^{14}$.

Przytoczone przeze mnie wypowiedzi nie pozostawiają, w moim przekonaniu, żadnej wątpliwości. Mowa nienawiści, znieważanie lub oczernianie bliźnich są zachowaniami uznawanymi przez abp. Życińskiego za wyjątkowo niegodziwe. Bezbronność ofiar wymaga ingerencji państwa. Stąd nie można było się zgodzić z postulatem środowisk dziennikarskich, by skreślić z Kodeksu karnego art. 212 przewidujący karalność zniesławienia. Słowo wyrażające nienawiść do drugiej osoby lub grupy osób, pomówienia i zniewagi godzą w godność człowieka będącą jednym

\footnotetext{
12 Tamże, s. 188-189.

13 Tamże, s. 192-193.

14 Tamże, s. 193.
} 
z fundamentów porządku prawnego. W polskim prawie karnym ochrona przed tego rodzaju czynami jest właściwie uregulowana. Można mieć jednak pretensje do praktyki, szczególnie do prokuratury, gdyż bardzo często sprawy dotyczące tego rodzaju zachowań są umarzane z powodu „znikomego stopnia społecznej szkodliwości”. Widać, że teksty Księdza Arcybiskupa nie trafily jeszcze pod strzechy polskiej prokuratury. 